\title{
Accounting as an Instrument of Social Justice
}

\author{
Theresa F. Henry1, Athar Murtuza1, Renee E. Weiss ${ }^{2 *}$ \\ ${ }^{1}$ Seton Hall University, South Orange, NJ, USA \\ ${ }^{2}$ Queens College, City University of New York (CUNY), Queens, NY, USA \\ Email: theresa.henry@shu.edu, athar.murtuza@shu.edu, ${ }^{*}$ renee.weiss@qc.cuny.edu
}

Received 16 December 2014; accepted 9 January 2015; published 16 January 2015

Copyright (C) 2015 by authors and Scientific Research Publishing Inc.

This work is licensed under the Creative Commons Attribution International License (CC BY). http://creativecommons.org/licenses/by/4.0/

(c) (i) Open Access

\section{Abstract}

This article builds upon calls for a shift in the paradigm of the accounting discipline, away from preparing or certifying financial reporting of management activities aimed at maximizing shareholder wealth toward recognition that businesses must also be accountable to other stakeholders and indeed the community at large. If individuals in business apply a sound moral compass to their activities and decisions, we believe that commerce can shift toward outcomes that may not only satisfy shareholders but also contribute to the common good. In this article, we are concerned with the role of accounting and business education. We enumerate recommendations toward achieving this paradigm shift from profit maximization to social justice. In some cases, the instructor may implement changes in their pedagogy at their discretion, while in other cases the change may require approval at the department or at higher levels of the university administration. We begin with a discussion of recent accounting and financial reporting failures as well as the global financial crisis. The dangers created by risky practices of financial institutions "too big to fail" and the systemic risk of a global marketplace have not been resolved. We articulate the need for ethics in the accounting and business curricula, a need that is hardly satisfied by the one course typically offered by universities at the graduate level. We propose that businesses and the accounting profession can realize change by redefining accounting as an instrument of accountability. To accomplish this change, each university must critically examine its curricula and reflect topics and material most important to ethical and moral behavior, including borrowing from the liberal arts disciplines. Finally, this article shows how an interfaith approach grounded in social justice to infuse ethical and moral behavior within the accounting curriculum can work.

\section{Keywords}

Accounting Education, Ethics, Accountability, Social Justice

"Corresponding author. 


\section{Introduction}

In this paper, we recommend significant improvements to the curriculum and the system in which we educate and prepare accounting students. Our goal is to educate students to be successful not only as future members of a business community, but as members of their wider communities. We assert that faith matters in the business disciplines. We believe that by infusing faith into our teachings, we will facilitate a broader view of professional objectives and achievements. Shall we continue to reinforce students' expectations that pursuit of a business degree is a means to" success" and students' common measure of success as the ability to consume more? We argue for a shift in this metric. As Pope John Paul II stated, "It is not wrong to want to live better; what is wrong is a style of life which is presumed to be better when it is directed towards "having" rather than "being", and which wants to have more, not in order to be more but in order to spend life in enjoyment as an end in itself." (Pope John Paul II, 1991) [1]. The purpose of this article is to move toward a new paradigm in business education; that our objective and duties as universities, colleges, and educators is for students to thoroughly develop their interests and potential to "be" the best version of themselves. In this way, the best of each individual contributes to the best of the community, the common is good.

The Arabic word, Taqwa, means having faith in the Creator and in respecting the creation. Etymologically, the word Taqwa comes from the Arabic root W-Q-Y verb, ittaqá which means "to protect oneself” or "to be wary". The word is cognate to the Hebrew term tiqwah ("hope"), derived from the Semitic root Q-W-I. Hope and trust in God are integrally related. If you participate and share in the community of God's people, you have trust in God to fulfill his promises to the community. The word Taqwa would be a useful word to describe what accounting ought to be concerned with. The term, with its Middle Eastern roots, is similar to the East Asian idea of “mindfulness". In this paper, we further call upon educators to build students' understanding of their responsibilities, not only to themselves, but also to their community. That participation in the accounting profession is not simply a means of attaining wealth and material goods, but a means of contributing to the community of persons within the business community and the society at large. In this way, each person has a sense of wellbeing and purpose. Accounting must be viewed not merely as a system of record-keeping but more importantly, as an instrument of accountability.

If educators present accounting to students as an instrument of accountability, then it behooves one to not ignore the religious dimension that can promote social justice and eradicate economic exploitations of the powerless and weak. For too long, we have ignored the potential of religious injunctions for social justice. We can facilitate the realization of the emancipatory praxis of accounting by drawing upon the injunctions for social justice in various faith traditions. This paper shows how an interfaith approach grounded in social justice to infuse ethics and a broader knowledge base within the accounting curriculum can work.

In the following section, we discuss recent accounting failures and the global financial crisis that point to the compelling need for changes in the current accounting education pedagogy and curriculum. In Section 3, we assert that including an ethics course in the accounting curriculum is necessary, but on its own will not suffice to change a business environment that elevates profit maximization above ethical and socially responsible business activities. In Section 4, we call for a new paradigm for accounting as an "instrument of accountability". In Section 5, we provide recommendations of a faith based approach to the practice and pedagogy of accounting specifically and business in general, and we provide our concluding remarks in Section 6.

\section{Accounting Failures and the Global Financial Crisis}

The complexities of the modern corporate form of organization and global capital markets give rise to many new challenges. There is a separation of ownership from control that characterizes the modern corporate form. Owners (individual shareholders) hold diversified portfolios and as a result are disinterested in managing day-to day organizational activities. These shareholders appoint managers to act on their behalf, but the manager and shareholder's interests may not be perfectly aligned. Managers may act opportunistically to pursue their own interests rather than those of shareholders (Henry, 2010) [2]. Such opportunism may take place in spite of internal and external monitoring mechanisms aimed to protect shareholder interests.

The recent spate of large-scale corporate financial reporting failures such as the sub-prime mortgage crisis of 2008 and the accounting scandals faced by corporations like Enron, WorldCom, and Tyco, illustrates significant corporate malfeasance that was not prevented by corporate governance or market monitoring mechanisms. For example, a subcommittee of the US Senate Committee on Governmental Affairs, charged with investigating the 
role of the firm's Board of Directors in Enron's collapse, found that Enron's Board failed in its fiduciary responsibility to shareholders. The Board had knowledge of Enron's high risk accounting practices, its practice of off-balance sheet financing, and other management actions that created an illusion of sound financial performance, when there was none. The effects of Enron's failure were far reaching including the apparent suicide of its Vice-Chairman; the collapse of the accounting firm Arthur Anderson; the loss of jobs, pensions, and investments by Enron employees; and billion dollar losses to investors. Participants in this wide reaching failure included not only Enron's management, employees and board of directors, but also its external auditor and numerous outside financial institutions. The disaster of the sub-prime mortgages dwarfs the damage done by those who controlled Enron. But neither has led to holding the culprits accountable for what they perpetrated in terms of human suffering on the part of those who lost their homes and savings.

The significant financial innovations, global connectivity of investors and counterparties, and financial malfeasance spread what might otherwise have been a US market correction of a housing bubble to a global economic crisis in 2008. Mortgage companies offered adjustable rate mortgages to risky borrowers so that when interest rates ticked upward, these borrowers could not afford to make their payments. As housing prices peaked, many such borrowers became "under water" and lenders foreclosed on these loans. The increased securitization of these loans and foreign investment contributed to the global scale of the crisis. Investors had little information about the quality/riskiness of the underlying debt and relied on ratings determined by credit rating agencies. While rating agencies originally considered these securities to be high grade investments, eventually they downgraded many of them as the housing bubble burst and defaults of the underlying loans increased. The opacity of mortgage backed securities and other complex financial instruments created significant market uncertainty. Investors and banks were unable to assess their exposure to subprime related and other loan losses. Banks were reluctant to lend as they required liquidity to absorb their losses. Indeed, financial institutions around the globe sustained catastrophic losses as the credit crisis unfolded. After allowing the demise of Lehman Brothers, the US Government intervened with American International Group (AIG), a major seller of credit default swaps. With authorization provided by the Economic Emergency Stabilization Act of October 2008, the Treasury purchased troubled assets, primarily, but not limited to those backed by residential and commercial mortgages, from financial institutions.

Yet the business practices of these financial institutions also contributed to the crisis. In its announcement of a $\$ 13$ billion settlement with JP Morgan, the US Department of Justice (2013) [3] stated:

"The settlement includes a statement of facts, in which JPMorgan acknowledges that it regularly represented to residential mortgage-backed securities investors that the mortgage loans in various securities complied with underwriting guidelines. Contrary to those representations, as the statement of facts explains, on a number of different occasions, JPMorgan employees knew that the loans in question did not comply with those guidelines and were not otherwise appropriate for securitization, but they allowed the loans to be securitized-and those securities to be sold-without disclosing this information to investors. This conduct, along with similar conduct by other banks that bundled toxic loans into securities and misled investors who purchased those securities, contributed to the financial crisis.”

Financial institutions also securitized and invested in collateralized debt obligations, pooling various assets including lower rated, riskier tranches of mortgaged backed securities which credit agencies then rated AAA due to diversification of risk. Citigroup recently agreed to a settlement with the SEC for its role in structuring and selecting the assets pooled in a one billion dollar collateralized debt obligation (“CDO”). Citigroup failed to disclose to its investors that it selected the assets in the CDO and that it took a short position against the CDO.

The 2008 credit crisis and economic recession far exceed previous instances of accounting malfeasance and debacles. Given the depth of the crisis, it is incumbent on the accounting profession, the practitioners as well as the educators, to better educate both the accounting students and the public at large about the all too real financial dangers that are lurking which could threaten the very fabric of society.

\section{The Need for Reform That Goes beyond an Accounting Ethics Course}

What makes Beethoven's Fifth Symphony a wonder are not its starting notes, but their interplay throughout the symphony. A symphony needs a lot more than its starting notes to be a wonderful experience. Societies and universities must do more to increase the likelihood that students who enter the accounting profession act ethically, and conduct their work in a way that promotes businesses to do a better job preserving not only corporate 
resources, but also resources of individuals and society. An accounting ethics course by itself is not sufficient for even when well-designed, it merely represents the opening notes of a symphony. A very well designed accounting ethics course, which we will critique, does not go far enough. It does not question the culpability of the accounting profession in failing to be a guardian of public interest, let alone the common good of the humanity and the planet it inhabits.

Massey and Van Hise (2009) [4] document the history of the calls for ethical infusion in accounting curriculum which hitherto "have largely fallen on deaf ears". At the time of their paper, few institutions offered standalone accounting ethics courses. To answer this unmet need, they developed their own course, and after considering the limited time for additional content in the typical undergraduate accounting curriculum, the extent of ethics instruction needed, and the receptivity of the audience, the authors designed a three-credit, stand-alone ethics course for graduate students that would be an addition to integrated coverage of ethical issues within the undergraduate curriculum. Their course is a major departure from what is very often the approach to accounting ethics courses: a cursory look at the AICPA professional code and other regulatory mandates. The authors selected course content by "integrating insights we gleaned from the philosophy, ethics, accounting ethics, and education literatures". Through such gleaning, they claim to have created a course that extends further from the "boundaries of public accounting issues", in which the students are asked to simulate "ethical decision-making using principled approaches derived from classic philosophical theory". Table 1 presents topics covered by the

\section{Table 1. Topics covered by Massey and Van Hise course.}

\begin{tabular}{|c|c|c|}
\hline Topic & Description & Class Number \\
\hline \multirow[t]{2}{*}{ Course Logistics } & Intro \& Course Assessment Pretest. & 1 \\
\hline & Review/Wrap Up Guest Lecture & 28 \\
\hline \multirow[t]{3}{*}{ Ethical Concepts } & Review of Classic Philosophical Ethics & 2 \\
\hline & Ethical Decision Making Revisited & 8 \\
\hline & Moral Reasoning & 9 \\
\hline \multirow[t]{3}{*}{ Understanding the Profession } & The Nature of a Profession & 3 \\
\hline & Accounting as a Profession & 4 \\
\hline & Becoming a Partner & 18 \\
\hline \multirow[t]{3}{*}{ Ethics Code } & Codes of Ethics-Purpose & 5 \\
\hline & Professional Codes of Ethics & 6 \\
\hline & Corporate Codes of Ethics & 7 \\
\hline \multirow[t]{4}{*}{ Accounting Professional Ethics } & Ethical Issues Associated with Audit Practice & 16 \\
\hline & Whistle-Blowing-The Auditor's Perspective & 17 \\
\hline & Tax Ethics & 19 \\
\hline & Consulting Practice Ethics (SOX Practice Limitations) & 20 \\
\hline \multirow[t]{4}{*}{ Governance } & Corporate Governance & 10 \\
\hline & Officer Compensation & 11 \\
\hline & Whistle-Blowing Mechanics: Hotlines, Policies & 12 \\
\hline & Should a Person Blow the Whistle? & 13 \\
\hline \multirow[t]{2}{*}{ Playing the Numbers } & Aggressive Accounting/Client Side & 14 \\
\hline & Aggressive Accounting/Auditor Side & 15 \\
\hline \multirow[t]{2}{*}{ International } & International Business Ethics & 21 \\
\hline & International Accounting Ethics & 22 \\
\hline \multirow[t]{4}{*}{ Social Responsibility } & Socially Responsible Business & 23, 24 \\
\hline & Corporate Social Responsibility & 25 \\
\hline & Social Responsibility Audits & 26 \\
\hline & Privacy Audits & 27 \\
\hline
\end{tabular}


course during the 28 class periods it meets over the semester. We have categorized these topics for a more convenient analysis of what the course covers.

Massey and Van Hise (2009) [4] are correct in their assertion that the course they have developed covers more topics than those typically covered in other accounting ethics courses. The topics they add are philosophical ethical theories, the Code of Professional Ethics, and various cases that highlight some of the more well-known audit failures and management concerns including corporate structure and governance. On the nonpublic practice side, they have focused on governance structure (e.g., board composition, officer compensation, etc.) as well as whistle-blowing (e.g., the efficacy of whistle-blowing hotlines, whistle-blower's motivation, subsequent treatment of whistleblowers, and legal protection for whistle-blowers). The students also studied the reporting and/or auditing of privacy policies, social responsibility policies, and environmental policies and considered not just how a company becomes known as a socially responsible company, but also the costs and benefits associated with being a socially responsible company.

They give considerable attention to professional codes. They do not stop after considering the AICPA code for professional ethics, but also have their students examine other professional codes, such as those related to the practice of accounting in the non-public accounting sector (e.g., for-profit organizations, not-for-profit organizations, and municipalities). While covering the codes, their coverage ranges beyond mere facts to analyzing the reason behind such codes, and to examine why different types of organizations required different codes. In so doing, students compared and contrasted codes from the various sectors.

What they do, they have done well. Their concern with ethical theories and principles is somewhat limited given most of their students have had an undergraduate ethics course. They only devote one class period of the twenty-eight total to reviewing the four basic ethical approaches: consequentialist, non-consequentialist, virtue, and justice theories. Following this initial review of classical philosophical approaches to ethics, the students participate in an ethics simulation on-line that requires them to make decisions in line with the classical ethical approaches throughout the semester. Students discuss, debrief, and reflect upon the simulation exercises, which enhance their competence in the application of ethical concepts.

While the course and their paper deserve kudos, in our opinion, Massey and Van Hise [4] see accounting largely as a tool for investment and financial decisions. In their paper, there is no infusion of what we could call critical examinations of the profession itself or its paradigms: earning maximization and rational choice. While concerning oneself with the invisible hand and its ability to let investors and managers make rational choices to maximize their wealth, one ought to remember that there is much more to a human body, let alone a human being, than an invisible hand. Constraining accounting within its current model can only address symptoms, while leaving out what is the governing paradigm of contemporary accounting itself as a major contributing factor to the great financial crises that have ensued. Massey and Van Hise [4] claim to have taken material from other disciplines, but in truth they have not ventured beyond accounting. They barely touch other business disciplines. They touch upon Jesuit teachings but that is just a very small part of the course and their treatment of social justice is limited to discussing a case pertaining to Ben and Jerry, a premium ice cream maker. This paper does not in any way seek to belittle the great effort these authors have devoted to developing and then writing a paper about their course. Their paper adheres to professional tradition by citing appropriate research for almost everything the course does. Still, we find their discourse to be of the accountants, for the accountants, and by the accountants. The course does expose students to literature that goes beyond serving as an apologia for the profession, but they do not cite works that argue that the financial crises of the last three decades were abetted by the professional accountants and their practice. In the next section, we discuss a recent paper that seeks to change the way accounting is perceived in order to make accountants take their responsibility to protect the public interest. The paper and what it argues is in contrast to accounting ethics courses that do not question the current status quo.

\section{A New Paradigm for Accounting as an Instrument of Social Justice}

Rabbi Moses Pava (2010) [5] asserts that thinking is conceptual; and that conceptual thinking resorts to metaphors. Quoting Lakoff and Johnson (1980) [6], he underscores that "the way we think, what we experience, and what we do every day is very much a matter of metaphor." To accounting researchers metaphorically, accounting is a branch of applied finance, and as such, accounting is an instrument of rational actors engaged in profit maximization. This metaphor is consistent with positive accounting theory (Watts and Zimmerman, 1986) [7] 
which provides the foundation for hypotheses predictive of management accounting choices and contracting decisions. This metaphor spawned significant empirical research in that accounting performance measures are part of the firm's contracts; parties to the contracts can influence contractual outcomes and cash flows realized based on accounting choices. Positive accounting theory justifies the notion that accounting matters given the documented association between accounting performance measures and securities returns.

Tinker, Merino, and Neimark (1982) [8] discuss competing theories in accounting, particularly focusing on the social role played by accounting. Accounting is viewed as being independent and unbiased by many, however, the reality is that accountants have been influenced by a more utilitarian and marginalist view that has led to their more biased and questionable role in society. This behavior is often masked by accounting theories that "elevate instead its technical, factual and seemingly objective aspects." The authors offer that historical materialism is the most plausible basis for accounting theory. What role has value played throughout time in our society? The accountant's view of value in the more utility-based marginalist approach can be reconstituted so as to consider many critical social issues that have often been overlooked. So, for example, "Does behavioral accounting enhance or diminish the social value of production ....is it a manipulative practice that increases alienation or a legitimate improvement in production technology?” The authors question what conditions in history have led to greater corporate accountability and if auditing has increased the accountability of the accounting profession.

Pava (2010) [5] also notes that Baruch Lev, Professor of Accounting and Finance, New York University, took the identification of accounting as applied finance further by urging that "accounting and disclosure decisions should be viewed exclusively in terms of cost benefit analysis" and "stated clearly and unambiguously that accounting decisions should be made in the same way that other business decisions are made-i.e. through the use of the cost benefit criterion." According to Lev, "Disclosure activity does not differ in principle from other corporate activities, such as investment, production, and marketing. Disclosure shares with these activities the fundamental characteristics of providing benefits and incurring costs” (Lev, 1992) [9].

Unlike the dominant mode of accounting research discussed above, Pava (2010) [5] calls for changing our dependence on abstract thinking, and our conceptual system that plays a major role in defining our everyday realities. What Pava would like is a change in the governing metaphor of accounting from "accounting as finance" to "accounting as ethics." He maintains that the change in governing metaphor would allow accountants to rise above their self-interest and promote the public interest rather than ignoring it out of a sense of loyalty to their clients. Pava suggests that accountants should pay more attention to what Chief Justice Burger asked in his opinion on a matter brought before the US Supreme Court: "this public watchdog function demands that the accountant maintain total independence from the client at all times and requires complete fidelity to the public trust [10]."

Sen (1977) [11] argues that a choice based on a commitment is an exception that is sufficient to refute the economic dogma of the rational actor selecting the preference among ordered choices that maximizes his or her utility (welfare). Sen addresses the implied or metaphoric ordering of preferences: "It is possible to define a person's interests in such a way that no matter what he does, he can be seen to be furthering his own interests in every isolated act of choice”. A person acting on the basis of commitment is not making a choice to maximize his or her utility but one that is consistent with his moral judgment or culture.

Pava believes a paradigm change is possible for a number of reasons including "a recoil of academic management theorists and business ethicists" from "Milton Friedman's sparse stockholder view of the corporation in favor of a more complex stakeholder conception." He maintains that, "it has become increasingly difficult to maintain the caricature of economic man as a kind of lone ranger upon which the finance metaphor rests." Pava writes about the "increasing agreement, "among corporate decision-makers that corporations are responsible "to heed the needs, interests, and influence of those affected by their policies and operations" (Buchholz and Rosenthal, 2005) [12]. However, such a notion of corporate responsibility can be nullified if the kind of logic that construes corporations to be people is allowed as major currency.

Pava's (2010) [5] call to view accounting ethics not just as a competency to be outsourced to others in academia, but as the fundamental function of accounting itself is not new. Others have also made similar calls but these calls are not published in the prestigious accounting journals nor have such calls made it into accounting texts used widely. In fact, as we already showed, even a well-designed stand-alone ethics course, well-intentioned no doubt, fails to heed the call. Most business schools do not have accounting ethics course in place. Such omission goes a long way in freeing business majors from moral sensibilities. 
Sumantra Ghoshal (2005) [13] wrote, in his posthumously published paper, that by preparing ideologically inspired amoral theories, business schools have actively freed their students from any sense of moral responsibility. While looking at how accounting is practiced and taught, one can see the veracity of the statement made by Ghoshal. Yet, accounting need not be amoral; it can be an invaluable tool of equity and social justice. The absence of a curriculum that does not pervasively infuse ethics into the curriculum contributes in not holding accountable a profession that has abetted and aided the financial crises that occur with painful regularity, and that have brought the very existence of the national prosperity into question.

The recent debacles that are far more toxic in their impact on the world at large must collectively serve as a call to arms for business schools to reevaluate their programs. Clearly, preparing business students for entry to a very complicated workplace must involve more than conventional "technical” mastery of concepts and applications. The scale of participants in the Enron failure illustrate that a fledging business practitioner may encounter many influences and challenges from many different sources. The business student clearly requires a broader array of knowledge than was previously made part of conventional business curricula.

We agree with the call of many to ensure that the business and accounting curriculum include and promote an ethical component. This paper seeks, however, to show that an ethical infusion in accounting curriculum, while imperative, is only a small part of the problem that confronts not only the accounting educators, but all citizens of the United States and other countries that comprise today's global economies. The likelihood that this nation can go from being America the Beautiful to America the bankrupt is very real. The warnings issued by David Walker (2010) [14], Paul Volcker (2010) [15], Martha Nussbaum (2010) [16] are starting to sound like the warnings issued by prophets such as Jeremiah from the Old Testament. The problems they are talking about are real and are not localized to the western shore of the Atlantic. Ireland, Greece, Spain, Italy and Portugal pose very serious challenges to not only Europe, but the rest of the world as well.

Given the magnitude of the challenge that confronts the global economy, it is not enough to limit the remedy to calls, to a large extent unheeded, for an infusion of ethics within the accounting curricula. This paper builds on recent papers which have dealt with not only how to infuse ethics into the accounting curriculum but have gone beyond and argued for a change in how accounting itself should be perceived. Others like Young and Anisette (2009) [17] as well as Moberg and Seabright (2000) [18] have argued for teaching accounting and business in ways that also promotes moral imagination and empathy since that in turn makes us more human. We are also drawing inspiration from the call made by Tony Tinker (2004) [19] to accounting professionals of various sorts that, given the might of the global capitalism, it is important to deploy wider forms of education and cooperation among groups that seek similar goals in order to resist such might:

"More than ever before, religion and Marxism need to suspend their mutual suspicion and join in a careful, interrogation of capitalism [realizing] for ennoblement of Man-on-Earth.” The politics of accounting reform can also be construed in a correspondingly broad manner. They are not limited to self-and-state regulation, but also to continuing education, employee selection, the composition of educational programs, the judicious screening of new clients, the organizational structure of firms, the training of educators, the range of permitted products and services that firms can offer, the research undertaken by educators, policies affecting the recruitment and selection of both students and faculty.”

In keeping with Tinker's exhortations, this paper argues that accounting must be thought of as more than a tool for the financial investors. Accounting should not be limited to the preparation of financial statements. Instead of equating the word accounting to the physical act of counting, or even score-keeping, it should be presented as a means to explain, to account for, an instrument of accountability in organizational contexts, both public and private. This ethical responsibility of accountants should result in their making sound moral judgments in order to uphold the fairness of corporate practices. In doing so, accounting would become an instrument of social justice and the corporate failures, inequities, and losses suffered by so many in the past due to corporate financial reporting abuses and mismanagement would evolve into a more cohesive global society.

\section{Recommendations to Reform the Practice and Pedagogy of Accounting Specifically and Business in General}

\subsection{Take a Critical Look at What Is Taught}

It should come as no surprise to hear accounting educators talk about the limitation of the time and the amount of material they can be expected to cover. By examining what is taught, it may be possible to give less time to 
non-consequential items, and provide room for covering more consequential topics such as environmental literacy. Such suggestions bring forth protestations that the accounting faculties already have their hands full given the amount of material that needs be taught. The volume of traditional material including US generally accepted accounting principles, auditing standards, governmental standards, and now international standards covered often limits inclusion of new topics. We observe that the increased financial reporting requirements and standards with which firms must comply trickles down into our textbooks and classrooms. Devoting a course or a portion of a course to an already full curriculum is viewed as not feasible. How then do we infuse this notion of the common good into our students' hearts and minds?

The current baccalaureate degree dates back to the middle ages. The world has expanded greatly and so has the knowledge one needs to keep up with it. Though human life expectancy has increased, the 4-year degree continues to dominate our expectation of educational achievement. Our common sense demands that the time devoted to educate human beings be extended - unpopular though it may be with powers that allocate resources. The accounting profession actually agreed to extend the years of education needed to acquire the license to practice as a Certified Public Accountant (CPA) from 120 credit hours to 150 credit hours. However, no requirements for these additional credit hours were put into place, and therefore such credit hours are not well utilized in the final phase of the students' accounting education. Some institutions use the hours to teach students skills and competencies they should have learned in high school. More often than not, others chose to cover the extra accounting standards that have spawned since the increase in credit hours was approved. Hence those who advocate a well-rounded education for accountants, find themselves confronting the "no room in the inn" syndrome.

It may be time for accounting faculty to re-examine what they teach. We examined college accounting textbooks to gauge the content of material that accounting educators are teaching. Judging from our examination, it seems clear that the introductory financial accounting course over indulges in traditional accounting bookkeeping. The chapter on accounts receivable invariably uses almost seventy to eighty percent of its space on the debits and credits associated with the allowance for bad debts. It is hardly the kind of details that students taking introductory accounting need be force fed, all the more so because the majority of those taking the course are non-accounting majors. These students would be better served if they could segue into matters of personal finance and learning about borrowing and lending. They could be exposed to issues surrounding corporate governance and the rights of the stockholders. Most importantly, students could learn about how financial reporting fits into decision-making and be made aware of the many shortcomings of the financial information reported.

We see a similar tendency to overindulge in bookkeeping for LIFO/FIFO inventory cost flow assumptions. One could suggest it may be a better use of text space to lower the coverage of inventory flow methods in favor of a greater emphasis on supply-chain management and how it is being used by the likes of Dell and Wal-Mart. In this way, students can learn how managerial decisions affect all stakeholders, taking into consideration not only shareholder profits but also the welfare of employees, suppliers, customers, etc.

For more advanced accounting students, discussions on Revenue Recognition should not deal solely with the five steps of the new Revenue Recognition Standard or deviations from traditional revenue recognition practices. Revenue recognition is the most prevalent reason for accounting restatements (Kieso, Weygandt, and Warfield, 2013) [20]. The discussion of the Conceptual Framework should hone in on the Conservatism or Prudence Principle or even its effectiveness (FASB, 2010) [21]. Accountants and auditors are duly responsible to ensure that their financial reports do not overstate assets or income so as not to mislead investors. This should be at the forefront of their work as stewards of financial information. This idea should carry throughout the teaching of the various accounting rules and regulations so that students do not forget what should be the underlying framework that financial reporting is based upon.

A cursory awareness of accounting curriculum in the US makes one realize that all the courses taken by accounting students deal with the preparation of financial statements. There is also some emphasis on the relationship between the generation of accounting statements and information technology. It is quite rare to find a student who has been taught the behavioral impact of accounting information. The need for accountants who can read, write, and communicate continues unabated and so, the emphasis on teaching specific accounting knowledge must be revisited.

Given the time constraint confronting educators seeking to infuse ethics and a humane element in the management of work and lives, one should think about how to maximize the material covered by various learning 
tools. One way to do so would be to adopt the concept of "bundling" to pedagogy. Bundle topics together when feasible. To illustrate the point we are making, we would like to show how a well-known case intended to discuss transfer pricing also presents an opportunity for discussion of the Common Good Model. The Birch Paper Company Case has been called the most frequently used case published by Harvard Business School. In the words of its authors, it is a "classic case that has proven to be an excellent way to present, analyze, and evaluate transfer pricing issues." The case is only two pages long and not overloaded with an excess of data, but it has great depth as evidenced by ten pages of teaching notes, and continues to facilitate classroom discussions on transfer pricing. Given its subject, transfer pricing, and its implication for performance measurements of corporate divisions, it is appropriate to treat the case not simply as a tool to better appreciate transfer pricing, but to also to encourage the students to think about the role of business in the civil society. One could go even further and discuss the case in the light of the Common Good model, which we will discuss later in the paper. In addition to "bundling" topics, sharing of syllabi, integration across courses and disciplines, team teaching and the emerging information technology, can facilitate extending the analysis beyond profit maximizing implications to other concerns such as common good implications.

In addition to the Birch Paper Company case or others, accounting and business faculty can increase their use of real world examples of business endeavors that may or may not promote the common good. An example of the positive is the fact that the Minnesota Keystone Program is in its $30^{\text {th }}$ year of promoting charitable giving by Minnesota businesses. The program fosters a culture of corporate giving and provides ongoing recognition of participants by their peers and the community at large. Students can observe those firms that view their corporate mission as profit maximization as opposed to those which answer the call to serve a higher purpose.

\subsection{Emphasize and Facilitate Financial Literacy}

In 2006, then Federal Reserve System Chair, Ben S. Bernanke, emphasized the importance of financial literacy in testimony before the Senate Committee on Banking, Housing, and Urban Affairs (Federal Reserve, 2006) [22]. Such literacy improves the ability of consumers and investors to make informed credit and investment choices. Mr. Bernanke provided this testimony well before the sub-prime mortgage lending crisis in which countless poor and minority borrowers lost their homes, large corporations reported substantial impairment losses on their investments in the mortgage loan market, and the lending practices of numerous financial institutions including the largest US mortgage lender, Countrywide Financial Corp. came under federal investigation. Accounting educators have yet to make any serious efforts towards eradicating financial illiteracy. Arts or science majors are not likely to take accounting courses as their electives nor do accounting educators make serious effort to attract them to their courses (Murtuza, 2004) [23]. Others are quite concerned. Lussardi (2011) [24] reports on three linked national surveys of adults in the U.S conducted in 2009 to assess financial capability (making ends meet, planning ahead, choosing and managing financial products, and financial literacy and selfassessed skills). Overall, the results document a disturbingly low level of financial capability amount the US population with younger adults, minorities, and individuals with lower levels of education having lower capability than other groups. Specific indicators are that nearly half of respondents reported difficulty meeting their expenses; $23 \%$ of individuals with checking accounts reported overdrafts, $16 \%$ of individuals holding mortgages reported late payments, and $9 \%$ of those with retirement accounts reported taking loans on those accounts. A majority of respondents do not have funds set aside for an emergency, $42 \%$ have not tried to determine how much they need to save for retirement, and an overwhelming majority of respondents with children have not saved for their children's college education. Answers to financial literacy questions indicate that respondents lack financial literacy and have little understanding of basic concepts in economics and finance.

It is not enough to improve the public image of the bishops of accounting in order to deal with financial crisis; one must also educate the congregation so they could understand better how governments, businesses, and financial institutions are managing tax revenues, pensions, and investments. One is facilitating strong governance by making the lay people more financially literate, for it is the ordinary tax-paying public who has invested in public corporations and who have earned pension benefits through their working years. An improved public awareness of corporate abuses can be a major tool in preventing them from taking place. This would, in turn, prevent the complicity of public auditors, regulators, and even the politicians to go along with the corporate malfeasances.

Twenty-first century university graduates must be able to comprehend accounting information and what it 
communicates for their personal well-being as well as to function as informed citizens in a democratic society. Without adequate and functional accounting, individuals' comprehension and competency in areas such as personal finance, corporate governance, organizational management, and public policy decision-making are adversely impacted. They are unable to participate fully in such activities even though decision-makers in businesses and government are ostensibly carrying out these activities on behalf of the individual investors, employees, and citizens. It is beyond dispute that these are the very activities that are essential to the role of insuring viability of a civil society. They are the accoutrement of societies where such individuals may take for granted life, liberty, and the pursuit of happiness. If Americans are accounting illiterate and unable to make sense of material essential to their everyday life, they are needlessly restricted from engaging in activities germane to a democratic society. Tinker (2004) [19] stated: "If accountants in particular, and Americans in general, were less ignorant about such matters, they might be less inclined to be suckered into such a vile complicity". The "vile complicity" refers to the politicians and the lobbyists' ability to loot the public resources and interests aided by the failure of the media to better inform the public. Given the extent of the problem, we need an accounting reformation, not just by and for the priests but the laity as well ought to know how to account for personal, private, and public resources.

\subsection{The Importance of Liberal Arts Courses}

We must not ignore the potential of non-business courses to teach skills as well as competencies. We should try to integrate what students learn through these courses with what they learn in accounting and business courses. Students graduating with a Bachelor of Science in Business Administration take courses in general and liberal studies which cover social sciences, humanities, and natural sciences. In addition to the required general business and major courses, business students also study subjects such as English, Religion, Psychology, History, Science, Philosophy, and Mathematics. The business and accounting students in the United States devote almost two academic years, nearly 60 credit hours, to liberal studies. Traditionally, the required liberal studies courses are the primary tools designated to impart a well-rounded education to the undergraduate accounting and business students. But a vast number of students all too often view these courses as a hurdle which they must jump over in order to get to, what is in their view, the important classes, those which will teach them what they really need to know as they begin their business careers. As a result of such attitude, they fail to attain a well-rounded education.

There are many likely reasons for this but one, in particular, could be the failure of business courses to insist on students' retention of competencies acquired through general and liberal studies. Students also suffer from the tendency of the profession to rank communicability of the information provided by financial reports as a low-level priority. The accounting professionals have often assumed that the information they prepare and provide are useful to individuals and to society at large without ascertaining how their utility may be impeded. Nor does it seem much attention is given by typical accounting professionals to ascertaining whether or not the financial statements do carry out communicative actions expected of them. A bean counters' nonchalance about the ability of those who use the financial information is aptly documented in the first FASB Statement of Concepts, paragraph 34 (2008) [25]: [The accounting] information should be comprehensible to those who have a reasonable understanding of business and economic activities and are willing to study the information with reasonable diligence (emphasis added).” According to the Statement, if you do not comprehend accounting information, you lack reasonable understanding and you are not diligent enough. This is hardly the case. Familiarity with business and reasonable diligence may still not suffice to help one understand how earnings per share or even cost allocations are conjured.

Yet another manifestation of such nonchalance is seen in the absence of any courses in accounting curriculums concerned with the communicational efficacy of financial statements. Every course with an accounting prefix is aimed at preparation of reports and not with their communication, measuring their usefulness, or the impact their format has on society and social justice. Accounting students are taught how to prepare reports but not how to effectively communicate the information contained in those reports. Certainly, a modicum of accounting teaching resources ought to be devoted to doing just that, to better and more effectively communicate the information submerged in the accounting discourse. A contributing factor to this communicational incompetence of many accountants is the perception that communication skills of accountants are limited only to the skills having to do with reading, writing, and speaking while maintaining eye-contact with one's listeners. To 
effectively communicate financial information to corporate stakeholders, other factors are also important beside competent knowledge of grammar and punctuation.

A great deal has been said about the weakness of business programs. Educators are failing our students terribly if they leave our university with viewpoint akin to Charles Dickens' character Gradgrind if not Bitzer. Martha Nussbaum shows that Gradgrinds are gaining ground and thus putting democracy and civilization in grave danger $(1996,2010)$ [16] [26]. A liberal arts education should serve to broaden the students' horizons. It should open their minds to the other disciplines and ideally, to see how those disciplines form the building blocks of their business education. For instance, the study of liberal arts came long before the development of double-entry bookkeeping. The liberal arts courses that students are required to take should help them to see how their business education and their future business careers fit into the bigger picture.

A liberal arts education develops the students' strength of mind and gives them an ordered intellect. Each of the required courses differentially help the students learn to think for themselves by ordering their thoughts. The world, therefore, and the interplay between different facets of the world become understandable to students. As strength of thought is developed, so too is the ability to learn. Students should be taught to apply the learning habits they developed in the liberal arts courses to their business courses. The general knowledge they acquire from their liberal arts courses will enhance their creativity and broaden the skill sets they will bring to their business education and careers (Harris, 1997) [27].

The challenge to the business educator is helping students to not only see that connection but also to believe it and appreciate the liberal arts education they are receiving. That challenge should be shared with those faculties instructing our students in the liberal arts. There needs to be a constant reminder of the connection between liberal arts and business throughout the students' education. A great deal of accounting curriculum lacks intellectual content and critical thinking. It is our responsibility to provide this link to ensure that students do not view any one course as a silo which has no bearing on their overall development. As business educators, we can provide this link in several ways. First, we can discuss our business course in the context of their overall education. For example, what is the history of accounting? Luca Pacioli is credited with the development of double entry accounting in his treatise, Summa de Arithmetica, Geometria, Proportioni et Proportionalita, published in Venice in 1494. However, even before that publication, there had been a long evolution of "accounting" in ancient times (CPA Finder) [28]. Accounting students do not usually know about the evolution of accounting from its clay-tablets birth. Nor do they know much about the Venetian world in which Pacioli lived. As educators, we can liberate our teaching from being confined to the desks and lectern of a classroom in a physical location at one given time. Such liberation should be used to enrich the students' educational journey. Students regard business as a modern invention but it is important that they realize that the history of accounting and other business disciplines is one small slice of our world history.

The second way that we can we can improve accounting students' abstract and critical thinking is by getting the student to connect their liberal arts and business education. This can be done by getting them to apply the tools used in liberal arts courses to their business courses. Writing and communication are an obvious but critical means that we must be using to continually develop our students' skill set. Projects involving a competition among groups within a class can help students explore the psychology of human thought. As we use these liberal arts tools, we should draw the students' attention to the courses in which these tools were originally developed. Given such an objective, it may even be worthwhile to teach accounting not as a something consisting of generally accepted accounting principles, but as discourse.

Our liberal arts and religious faculty can help to foster an environment which embraces liberal arts studies. They can encourage students to continually think about their chosen discipline and ask them to place that discipline within the context of the liberal arts course. The university should strengthen the connection between the liberal arts and business education throughout the students' curriculum. Liberal arts have a greater ability to evoke from students a sense of emotion. This better allows students to visualize and empathize with those in the world who are victims of hunger, disease, and injustice. This collaboration between the business educators and our liberal arts colleagues will graduate students who are well rounded, skilled, socially conscious, and poised to face the challenges of the business world.

Even though accounting and other professionals involved with providing information resources have not yet tried to make use of literature in their curricula, other professions have been using alternative resources such as literature to enhance their teaching. There is a considerable body of research in journals such as Critical Perspectives on Accounting, Accounting, Organization, \& Society, and Accounting, Auditing, and Accountability 


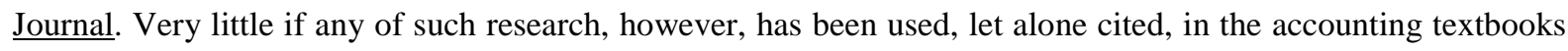
used to teach accounting in the United States.

A benefit of using material usually associated with liberal arts is to help make accounting students value and retain the skills and attitudes taught in liberal studies courses. They are more likely to do so if they are called upon to use those skills in their accounting courses. This would be an apt way to make them view the knowledge gained in liberal arts courses as stepping stones that help reinforce what they are learning in accounting and business courses. Such reinforcement of skills learned in liberal studies courses would, in turn, mean that accounting teachers are not outsourcing teaching the human aspects of accounting information communication and knowledge management entirely to the arts and science faculty. Communication and human behavior should not be left entirely to the liberal studies. Accounting and business courses must reinforce what is taught in liberal studies courses.

By using literary works, one is likely to accrue the kind of benefits usually associated with experiential learning, case studies, and what has come to be called unstructured learning (Young and Annisette, 2009) [17]. The use of literary works alongside other teaching resources can very likely promote critical thinking skills that are almost universally desired. Using the material normally associated with the non-business and non-accounting courses in the accounting courses seems a good way to help cure the tendency to see liberal arts and humanities as stones to step over. It can impress upon students studying business disciplines that there is more than one way to approach the realities of the world we inhabit and learn the skills to deal with them. The discourse associated with social sciences and humanities overlaps to a considerable degree the objectives associated with the models of decision theory and this is well worth an acknowledgement in the business and accounting curricula.

\subsection{The Infusion of Faith}

As educators, we must not lose sight of our role in not only providing the skills necessary for our graduates to become tomorrow's business leaders, but more importantly in developing the persons who will be those leaders. In his Centestimus Annus, Pope John Paul II (1991) [1] said, "Indeed, besides the earth, man's principal resource is man himself. His intelligence enables him to discover the earth's productive potential and the many different ways in which human needs can be satisfied."Our responsibility, therefore, does not end with the development of the students' mind but must include the cultivation of their hearts and souls as well. We want to graduate business leaders who are not only intelligent and capable, but moral and ethically grounded.

Our business press has, unfortunately, been filled with accounts of inappropriate and unethical behavior by individuals ruling our corporations. One wonders, at what point does an individual's moral compass become so distant from the person he once was? At what point did that individual lose his way in life? Our faith is a tremendous part of the moral backbone which we bring to our workplace. In his April 2008 visit to the United States, Pope Benedict XVI addressed educators from around the country saying, "Clearly, then, Catholic identity is not dependent upon statistics. Neither can it be equated simply with orthodoxy of course content. It demands and inspires much more: namely that each and every aspect of your learning communities reverberates within the ecclesial life of faith.” (Reilly, 2008) [29]. We must incorporate that faith throughout our curriculum so that students realize that their actions will be forever governed by a higher purpose.

Our capitalistic business model encourages competition in the market place. That competition is measured in profits. As business educators instructing our students in accounting, we must be clear about the role that profits play for a corporation. We must emphasize the duty that business leaders have to their shareholders, employees, suppliers, etc. Pope John Paul II (1991) [1] said, "Profit is a regulator of the life of a business, but it is not the only one; other human and moral factors must also be considered which, in the long term, are at least equally important for the life of a business.”Our students must be aware that achieving financial success for themselves and their business should not be their only goal. Therefore, our role is to not only instruct them in the attainment of profits. From either the Jewish, Christian, or Islamic perspective, our focus should be on the need to develop the student, the person, as a whole.

The world, inhabited by Jews, Christians, Muslims, and others, is confronting an ever increasing secular consumerism that is wreaking havoc on human happiness. The crises of the sub-prime mortgages and others illustrate how globalization is adding to human greed and exploitation. Combine this with environmental issues, rampant world hunger, and so on, and it becomes clear that to deal with a growing concentration of resources in the hands of the wealthy, we need to embrace an interfaith approach. As many as 30, 000 adults (Scutti, 2014) 
[30] and an equal number of children under the age of five (Unicef) [31] die daily of preventable causes. The time has come for change and this requires the various faiths of our world to pool their efforts. The Business School can help by teaching its students the awareness of dangers that confront human survival. The skills taught in Business curriculums need to be infused by values for social justice that Judaism, Christianity, Islam and other faiths have in common. Faith does matter and by infusing an interfaith approach into the accounting curricula, we cross the barriers of prejudice. We teach our students the respect and concern for all people of varying faith, race, and ethnicity.

We advocate an interfaith approach to accounting education that will facilitate financial responsibility on a personal, corporate, and global level. In spite of differences in economic models around the world, an education that promotes financial responsibility and concern for the common good should help to build bridges across these differences. Such bridges will begin to address many of the economic problems that beset humanity. We envision an accounting program that integrates generally accepted accounting principles, Taqwa, and the Common Good, emphasizing that faith truly does matter.

The Qur'an calls itself the guidance for those who have Taqwa. Among the various meanings of the word Taqwa are: conscience, fear, righteousness, awareness, constant consciousness of God, being in awe of God's greatness, and even the fear of God's judgment. It is seen as the inner torch that illuminates the right choice for those seeking to do good both in matters pertaining to sacred and secular spheres. In short, it means the awareness of His all-presence and the desire to mold one's existence in the light of this awareness. It may even be seen as having much in common with the Buddhist notion regarding "mindfulness."

The Qur'an provides, what may be probably the most succinct definition of Taqwa: "(2:177): True piety does not consist in turning your faces towards the east or the west, but truly pious is he who believes in God, and the Last Day; and the angels, and revelation, and the prophets and spends his substance, however much he himself may cherish it, upon his near of kin, and the orphans, and the needy, and the wayfarer, and the beggars, and for the freeing of human beings from bondage; and is constant in prayer, and renders the purifying dues; and [truly pious are] they who keep their promises whenever they promise, and are patient in misfortune and hardship and in time of peril: it is they that have proved themselves true, and it is they, they who are conscious of God." Given the above quotation from the Qur'an, one can equate Taqwa with having faith and promoting social justice. It may be construed to represent living and managing one's life and business as if faith mattered and social justice is important. All faith traditions enjoin one to follow the Golden rule set forth by Jesus Christ: "So whatever you wish that others would do to you, do also to them, for this is the Law and the Prophets." (The Holy Bible, 2011, Matthew 7:12) [32].

Generally accepted accounting principles are the standards formed by accounting authoritative bodies whose goal is to make the accounting information presented in a firm's financial statements a fair and accurate representation of the firm's true economic condition. The authoritative bodies are secular but their purpose is to enhance the quality of financial reporting for the good of all stakeholders. We have witnessed the manipulation of such financial information to the detriment of stakeholders so the question remains: how do we as a society and educators integrate Taqwa and concern for the common good into our stakeholder model to ensure that individuals reporting such information are driven by a higher purpose. A possible approach is shown by Alford and Naughton (2001) [33] who promote a common good model. Working towards the common good, therefore, is not merely concerned with profit maximization but also includes the human asset which is often ignored in accounting. The Jewish, Christian, and Muslim doctrines are monotheistic, adhering to the existence of one and only one God. Each doctrine has its respective source of knowledge, the Torah, the Bible, and the Qur'an. The knowledge within these books was transcribed by religious officials but originally imparted through divine revelation. This revelation can be achieved through the human senses. Shema Yisrael Adonai Eloheinu Adonai Echad. "Hear, O Israel! The LORD is our God! The LORD is One!” The Qur'an refers to learning by seeing, "The Eye of Certainty". The revelation can be delivered by a messenger: Muhammad as a messenger of God in Islam; Moses as a messenger delivering the laws of God in the Judeo-Christian faiths; and Jesus Christ, the Son of God as a deliverer of God's message and salvation in the Christian faith. In each religion, the recipients of the message consider it to be a treasured gift from God, a gift that nonetheless imposes a responsibility on the recipient. In each faith, God's communication, embodied in the respective scriptures, provides guidance for how to live one's life, as a human being and as a member of a community.

From a Catholic perspective, we are taught by Jesus Christ to love one another. The New Testament is replete with passages indicating Christ's intentions that we treat each other with love and respect. "For the whole law 
can be summed up in a single commandment, namely, 'You must love your neighbor as yourself.'” (The Holy Bible, 2011, Galatians 5:14) [32].”A new command I give you: Love one another. As I have loved you, so you must love one another. By this everyone will know that you are my disciples, if you love one another."(The Holy Bible, 2011, John 13:34-35) [32]. It is clear that Christ does not want us to live a life which is self-serving; rather we must always keep the needs of our "neighbor" in mind. Neighbor is, of course, not to be interpreted literally, but rather represents every human being that we come in contact with.

Maimonides, a medieval Jewish philosopher, formulated thirteen core principles of Judaism that must be observed by those who wish to be part of the Jewish community of Israel, and once part of this community, are to be treated with love and compassion, as God has commanded. Simeon "the Just" (named for his piety and benevolence) is credited with emphasizing three principles; study (torah), service (avocat) and acts of loving kindness (gemilut hasadim). In the Muslim tradition, divine revelation is meant to guide human behavior. It allows human beings the ability to realize their inherent goodness through God's guidance.

In developing this article, three accounting faculty have come together to reflect on the common elements of their respective religions. We believe such reflection is vital in a time when our business and accounting students face an increasingly complex landscape that poses many moral and ethical challenges. We believe the common elements of our respective religions call us to raise a question beyond how we can prepare our students to benefit as individuals from their work inputs. We must also raise the question about how our students can apply their work to benefit not only themselves, and their employers, but also the greater community of human beings. Our shared spiritual values and an interfaith dialogue can provide much needed support to students facing this very significant endeavor. Recognizing the common elements of different faiths and ideologies is a most important step to building bridges across differences, and reaching out to all human beings to improve the welfare of not just some, but all. Faith does matter and infusing faith into the accounting curricula will help students to understand the role of accounting better by providing them with that higher purpose we hope they will serve.

\section{Concluding Remarks}

This paper, written by three accounting educators, a Jew, a Catholic, and a Muslim, seeks to show how one could infuse concerns for common good and social justice as prescribed by the major faith traditions in accounting curricula which is currently governed largely by secular and amoral strictures such as generally accepted accounting principles. The emphasis on importance of social justice and common good should be fundamental to business and accounting education, much more so than the current emphasis on promoting earnings maximization. This should be the case irrespective of one's religious beliefs or a lack of them.

Unfortunately, accounting education tends to focus on a profit maximization model, thus ignoring the implications of obsessive pursuit of profit on the human condition. Besides seeking to inculcate a concern for justice and good, this paper shows how best to optimize efforts directed to counter if not subvert the seemingly single minded devotion to profit at the expense of other considerations. It is not enough to plant seeds by developing a course in accounting ethics; one must also nourish and protect what sprouts from the seeds in order to ensure a fair harvest. This can be achieved by emphasizing the importance of liberal and general studies and the knowledge and skills gained from such courses. Such skills should be intertwined with the accounting and business education so that students do not view them as separate but rather their entire education as one whole. As educators, our goal is to educate not merely astute business people but individuals who abide by the common good and who realize that faith does matter.

\section{References}

[1] Pope John Paul II. (1991) “Centesimus Annus” on the Hundreth Anniversary of Rerum Novarum. http://www.vatican.va/holy_father/john_paul_ii/encyclicals/documents/hf_jp-ii_enc_01051991_centesimus-annus_en. $\underline{\mathrm{html}}$

[2] Henry, T.F. (2010) Does Equity Compensation Induce Executives to Maximize Firm Value or Their Own Personal Wealth? Advances in Public Interest Accounting, 15, 111-139. http://dx.doi.org/10.1108/S1041-7060(2010)0000015008

[3] US Department of Justice (2013) Justice Department, Federal and State Partners Secure Record \$13 Billion Global Settlement with JPMorgan for Misleading Investors About Securities Containing Toxic Mortgages. http://www.justice.gov/opa/pr/2013/November/13-ag-1237.html

[4] Massey, D.W. and Van Hise, J. (2009) Walking the Walk: Integrating Lessons from Multiple Perspectives in the De- 
velopment of an Accounting Ethics Course. Issues in Accounting Education, 24, 481-510. http://dx.doi.org/10.2308/iace.2009.24.4.481

[5] Pava, M.L. (2010) Teaching Accounting Ethics: A Thought Experiment. Working Paper. Sy Syms School of Business, Yeshiva University, New York.

[6] Lakoff, G. and Johnson, M. (1980) Metaphors We Live By. University of Chicago, Chicago.

[7] Watts, R.L. and Zimmerman. J.L. (1986) Positive Accounting Theory. Prentice Hall, Inc., Englewood Cliffs.

[8] Tinker, A., Merino, B. and Neimark, M.D. (1982) The Normative Origins of Positive Theories: Ideology and Accounting Thought. Accounting Organizations and Society, 7, 167-200. http://dx.doi.org/10.1016/0361-3682(82)90019-8

[9] Lev, B. (1992) An Information Disclosure Strategy. California Management Review, 34, 9-30. http://dx.doi.org/10.2307/41166701

[10] (1984) United States v. Arthur Young \& Co. et al., US Supreme Court, No. 82-687.

[11] Sen, A.K. (1977) Rational Fools: A Critique of the Behavioral Foundations of Economic Theory. Philosophy and Public Affairs, 6, 317-344.

[12] Buchholz, R.A. and Rosenthal, S.B. (2005) Toward a Contemporary Conceptual Framework for Stakeholder Theory. Journal of Business Ethics, 58, 137-148. http://dx.doi.org/10.1007/s10551-005-1393-8

[13] Ghoshal, S. (2005) Bad Management Theories are Destroying Good Management Practices. Academy of Management Learning \& Education, 4, 75-91. http://dx.doi.org/10.5465/AMLE.2005.16132558

[14] Walker, D.M. (2010) Comeback America: Turning the Country Around and Restoring Fiscal Responsibility. Random House, New York.

[15] Volcker, P. (2010) The Time We Have Is Growing Short. The New York Review of Books. http://www.nybooks.com/articles

[16] Nussbaum, M. (2010) Not for Profit: Why Democracy Needs the Humanities. Princeton University Press, Princeton.

[17] Young, J.J. and Annisette, M. (2009) Cultivating Imagination: Ethics, Education and Literature. Critical Perspectives on Accounting, 20, 93-109. http://dx.doi.org/10.1016/j.cpa.2007.03.003

[18] Moberg, D.J. and Seabright, M.A. (2000) The Development of Moral Imagination. Business Ethics Quarterly, 10, 845884. http://dx.doi.org/10.2307/3857836

[19] Tinker, A. (2004) The Enlightenment and Its Discontents Antinomies of Christianity, Islam and the Calculative Sciences. Accounting Auditing \& Accountability Journal, 17, 442-475. http://dx.doi.org/10.1108/09513570410545812

[20] Kieso, D.E., Weygandt, J.J. and Warfield, T.D. (2013) Intermediate Accounting. 15th Edition, John Wiley \& Sons, Inc., Hoboken.

[21] FASB (2010) Statement of Financial Accounting Concepts No. 10. http://www.fasb.org/cs/BlobServer?blobcol=urldata\&blobtable=MungoBlobs\&blobkey=id\&blobwhere=11758228926 35\&blobheader=application/pdf

[22] Federal Reserve, Board of Governors (2006) Testimony of Ben S. Bernanke on Financial Literacy before the Committee on Banking, Housing, and Urban Affairs of the United States Senate. http://www.federalreserve.gov/newsevents/testimony/bernanke20060523a.htm

[23] Murtuza, A. (2004) Teaching Non-Business Majors How to Decipher Accounting Discourse. Working Paper, Seton Hall University, South Orange.

[24] Lussardi, A. (2011) Americans’ Financial Capability. Working Paper, National Bureau of Economic Research.

[25] FASB (2008) Statement of Financial Accounting Concepts No. 2. http://www.fasb.org/cs/BlobServer?blobcol=urldata\&blobtable=MungoBlobs\&blobkey=id\&blobwhere=11758209005 26\&blobheader=application\%2Fpdf

[26] Nussbaum, M. (1996) Poetic Justice: The Literary Imagination and Public Life. Beacon Press, Boston.

[27] Harris, R. (1997) Evaluating Internet Research Sources. Virtual Salt. http://www.virtualsalt.com/evalu8it.htm

[28] CPA Finder. History of Accounting. http://www.cpafinder.com/accounting/history-accounting.html

[29] Pope Benedict XVI (2008) Meeting with Catholic Educators. Washington DC. http://www.vatican.va/holy_father/benedict_xvi/speeches/2008/april/documents/hf_ben-xvi_spe_20080417_cath-univwashington en.html

[30] Scutti, S. (2014) Why Are Vaccination Rates So Low? Medical Daily. http://www.medicaldaily.com/why-are-vaccination-rates-so-low-30000-adults-die-each-year-vaccine-preventable-illne 
Sses-268698

[31] Unicef. Goal: Reduce Child Mortality. http://www.unicef.org/mdg/childmortality.html

[32] The Holy Bible, New International Version, 2011.

[33] Alford, H.J. and Naughton, M.J. (2001) Managing As If Faith Mattered. University of Notre Dame Press, North Bend. 
Scientific Research Publishing (SCIRP) is one of the largest Open Access journal publishers. It is currently publishing more than 200 open access, online, peer-reviewed journals covering a wide range of academic disciplines. SCIRP serves the worldwide academic communities and contributes to the progress and application of science with its publication.

Other selected journals from SCIRP are listed as below. Submit your manuscript to us via either submit@scirp.org or Online Submission Portal.
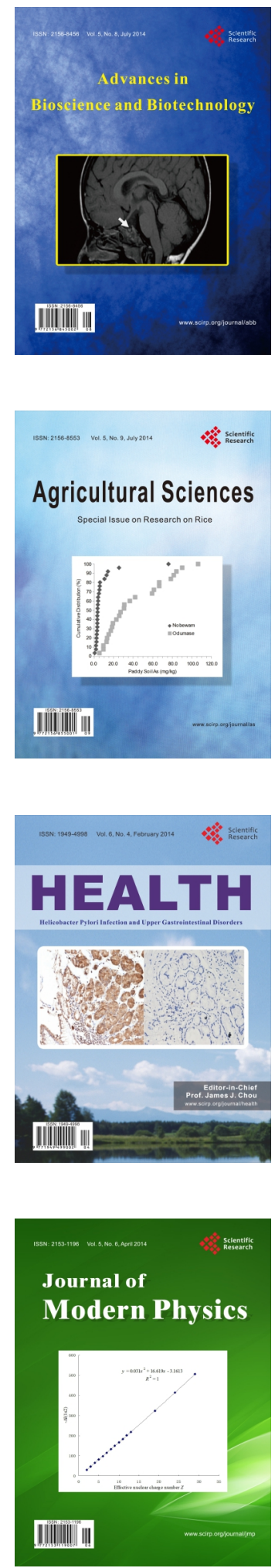
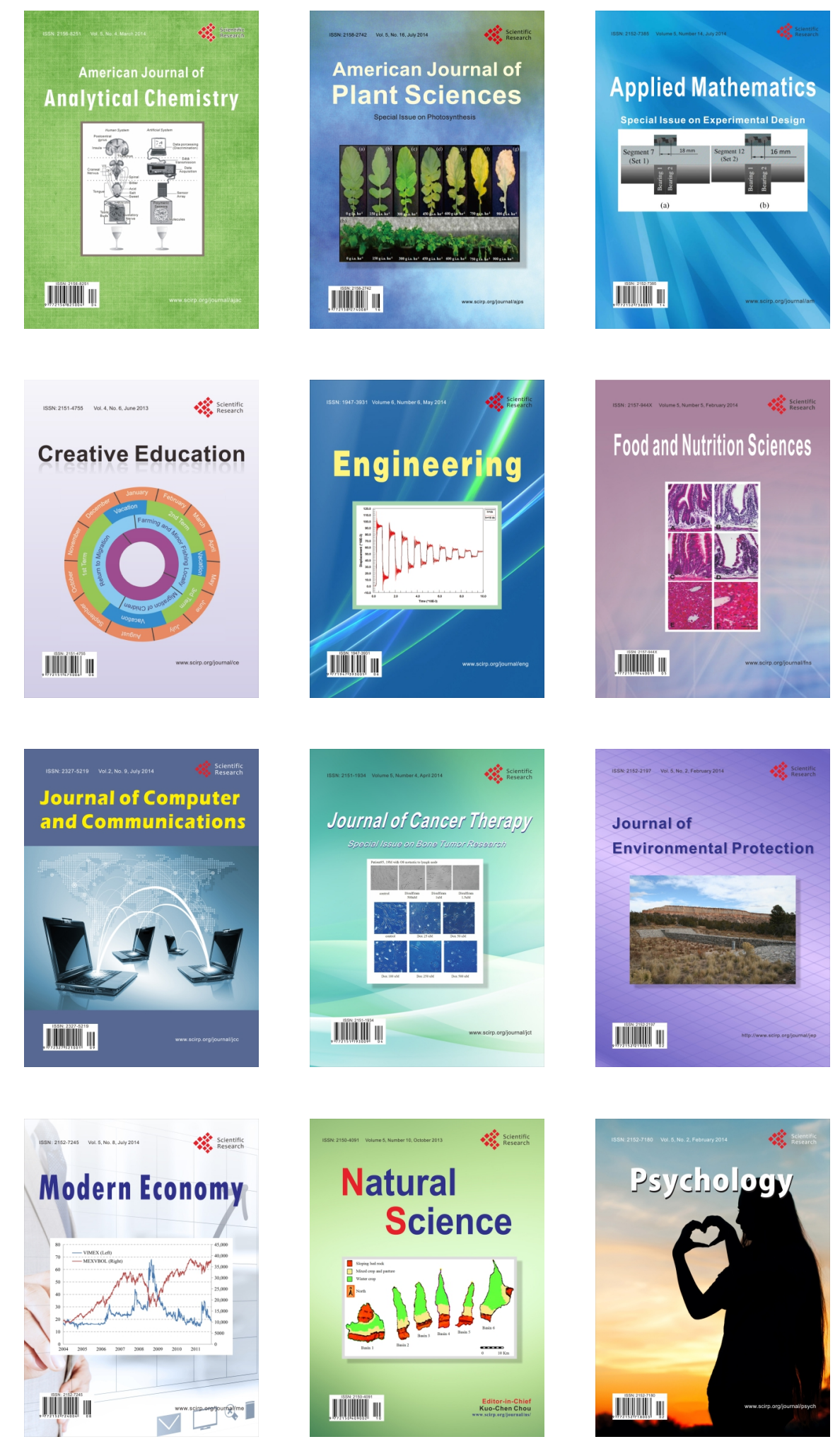